\title{
Zofia ZAWADZKA
}

Uniwersytet w Białymstoku

\section{Infotainment a ochrona prywatności osób powszechnie znanych}

$\mathrm{T}$

abloidyzacja to zjawisko polegające na zrównaniu poważnych, opartych na faktach wartości materiału informacyjnego $\mathrm{z}$ wartościami kojarzonymi z tabloidami, czyli powierzchownością, sensacyjnością, pospolitością . Jest ona przejawem spopularyzowania i ,zmiękczenia” twardych wartości materiału informacyjnego. Wydźwięk tego pojęcia ma charakter jednoznacznie pejoratywny ${ }^{2}$. Podkreśla się, że połączenie twardych informacji z miękkimi prowadzi w konsekwencji do przyznania pierwszeństwa plotkom, sensacjom i skandalom, gwiazdom i wydarzeniom sportowym, przy jednoczesnym odsunięciu na drugi plan zagadnień z zakresu polityki, gospodarki, ekonomii czy kultury. W konsekwencji prowadzi to do tego, że różnice między wiadomościami a rozrywką stają się coraz mniej dostrzegalne.

Przejawem procesu tabloidyzacji jest zjawisko infotainment. Inforozrywka wywodzi się z tradycji tabloidu i jest skoncentrowana na atrakcyjnych i ekscytujących aspektach opisywanych zdarzeń i przedstawieniu ich w taki sposób, aby były zdarzeniami rozrywkowymi ${ }^{3}$. Infotainment jako zbitka słów: information i entertainment, czyli informacja i rozrywka charakteryzuje materiał, który ma jednocześnie informować i bawić, czyli prezentować informacje w sposób rozrywkowy ${ }^{4}$. Zabawa polega nie tylko na prezentowaniu treści w formie lekkiej, ale również za po-

1 S. Allan, Kultura newsów, Kraków 2006, przekł. A. Sokołowska, s. 215.

2 Ibidem, s. 235.

3 P. M. Dmitruk, Jak sprzedać informację? Seks, humor i sensacja w prasie, Poznań-Opole 2011, s. 31.

4 T. Goban-Klas, Ksztatcenie dziennikarzy w odniesieniu do prezentowania kataklizmów, katastrof, krachów, w: Studia dziennikarskie. Uwarunkowania teraźniejszości, wyzwania przyszłości, red. S. Gawroński, Kraków-Rzeszów-Zamość 2011, s. 62; Z. Bauer, Gatunki dziennikarskie, w: Dziennikarstwo i świat mediów, red. Z. Bauer, E. Chudziński, s. 261; S. Allan, Kultura newsów..., op. cit., s. 215. 
średnictwem thrillerów czy horrorów prezentowanych w uspokajającym kontekście wiadomości z kraju i ze świata ${ }^{5}$.

W doktrynie infotainment określany jest jako forma dziennikarskiej relacji, w której informacje przeplatają się z elementami rozrywkowymi i której celem jest pozyskanie jak największej liczby odbiorców ${ }^{6}$. Stanowi formę relacjonowania o ważnych sprawach publicznych, ale z przesunięciem akcentu z wartości informacyjnych na wartości rozrywkowe tematu. Infotainment charakteryzuje się pomieszaniem życia publicznego z prywatnym, używaniem sensacyjnego stylu i czasami sceptycznego, ale zawsze populistycznego tonu oraz zatarciem granicy między tym, co prawdziwe a fikcja, czyli między newsem a rozrywką ${ }^{7}$.

Infotainment jako zjawisko nadawania przekazowi medialnemu jednocześnie wartości informacyjnej i walorów rozrywkowych spowodowane jest procesem marketingu mediów ${ }^{8}$. Uznaje się, że prasa ma obecnie za zadanie nie tylko informowanie i interpretowanie rzeczywistości, ale także rozbawienie i zszokowanie odbiorcy, wywołanie w nim emocji tak, aby zwrócić i zatrzymać jego uwagę? . W celu osiągnięcia tego efektu styl wypowiedzi medialnej charakteryzuje się fragmentaryzacją, konkretyzacją, sensacjonizmem, a przede wszystkim personalizacją ${ }^{10}$. Wskazuje się, że wartość informacji wzrasta, jeżeli dotyczy wydarzeń konfliktowych, niespodziewanych, aktualnych, nagłych, negatywnych oraz spersonalizowanych i dotyczących elit ${ }^{11}$.

Zjawisko infotainment łączy się z wymogiem personalizacji informacji i odniesieniem ich do elit, aby były one bardziej atrakcyjne dla odbiorców. Personalizacja zakłada, że przedstawianie ludzkich postaci jest bardziej atrakcyjne niż opisywanie abstrakcyjnych bezosobowych sił, struktur, instytucji czy informacji ${ }^{12}$. Z kolei odnoszenie informacji do elit zakłada, że działania polityków, członków rodzin królewskich, gwiazd sportu i rozrywki są bardziej istotne niż działania zwykłych

5 T. Goban-Klas, Ksztatcenie dziennikarzy..., op. cit., s. 62.

6 S. Allan, Kultura newsów..., op. cit., s. 232.

7 W. Godzic, Znani z tego, że sq znani. Celebryci w kulturze tabloidów, Warszawa 2007, s. 64.

${ }^{8}$ P. M. Dmitruk, Jak sprzedać informację.., op. cit., s. 9.

9 Ibidem, s. 31.

${ }^{10}$ Ibidem, s. 32.

11 J. Bralczyk, J. Wasilewski, Język w mediach. Medialność języka, w: Dziennikarstwo i świat mediów, red. Z Bauer, E. Chudziński, Kraków 2008, s. 390.

12 S. Allan, Kultura newsów..., op. cit., s. 62. 
ludzi ${ }^{13}$. Personalizacja informacji, a tym bardziej personalizacja informacji poprzez odniesienie jej od osoby znanej i sławnej jest istotna, ponieważ celebryci są ważni dla społeczeństwa. W ich życiu skupiają się i odbijają różne aspekty życia społecznego ${ }^{14}$. Personalizacja jest wyrazem obecnego w mediach antropocentryzmu jako sposobu przekazywania informacji. Człowiek staje się coraz częstszym przedmiotem newsów i przekazów wizualnych w postaci zdjęć lub filmów ${ }^{15}$. To za pośrednictwem człowieka przekazuje się obecnie informacje - poprzez odniesienia do jego osoby, do przykładów z życia. Tendencja ta jest wyrazem przyjmowania punktu widzenia odbiorcy jako osoby, do której skierowany jest przekaz medialny.

W niniejszej publikacji rozważania skoncentrowane zostaną na aspekcie personalizacji informacji, w szczególności odnoszenia jej do osób powszechnie znanych oraz zagadnienia naruszenia prywatności. Należy bowiem wskazać, że cechą tabloidów i infotainment jest w szczególności wymieszanie rozrywki z newsem, poświęcanie większej uwagi ludziom niż sprawom, przekształceniu społecznych i ludzkich tragedii w taką formę, że stają się one tematem publicznych rozważań, służąc celom rozrywkowym ${ }^{16}$. Informacje są obecnie przekazywane za pomoca human stories, na konkretnych przykładach ze świata osób powszechnie znanych. Prowadzi to do naruszenia prywatności tej kategorii osób.

Analiza zagadnienia ochrony prywatności osób powszechnie znanych w kontekście zjawiska tabloidyzacji prasy wymaga przeprowadzenia rozważań o charakterze prawnoporównawczym na przykładzie niemieckiego porządku prawnego. Zagadnienie to było bowiem podejmowane w orzecznictwie sądów niemieckich. Bundesverfassungsgericht już w wyroku z 15 grudnia 1999 r. zwracał uwagę na zjawisko tzw. Infotainment, które polega na przekazywaniu informacji w formie rozrywki i coraz trudniejszym oddzieleniu obu tych funkcji ${ }^{17}$.

Zgodnie ze stanowiskiem Bundesverfassungsgericht wolność prasy obejmuje również materiały prasowe o charakterze czysto rozrywko-

13 Ibidem, s. 63.

14 W. Godzic, Znani z tego, że sq znani..., op. cit., s. 23.

15 T. Piekot, Dyskurs polskich wiadomości prasowych, Kraków 2006, s. 209.

16 M. Palczewski, Kilka uwag o tabloidyzacji newsa, w: News i dziennikarstwo śledcze wobec wyzwań XXI wieku, red. M. Palczewski, M. Worsowicz, Łódź 2010, s. 78 .

17 Wyrok BVerfG z 15 XII 1999 r., 1 BvR 653/96, NJW 2000, s. 1021, § 98. 
wym. Bundesverfassungsgericht podkreśla, że rola prasy polegająca na budowaniu opinii publicznej nie wyłącza celów rozrywkowych z konstytucyjnie chronionych zadań prasy. Bundesverfassungsgericht nie wyklucza, aby rozrywkowy charakter publikowanych treści mógł mieć wpływ na budowanie opinii publicznej. Aprioryczne zanegowanie możliwości wnoszenia wkładu w debatę publiczną przez artykuły o tematyce rozrywkowej prowadziłoby - zdaniem Bundesverfassungsgericht - do naruszenia wolności prasy zagwarantowanej w art. 10 Europejskiej Konwencji Praw Człowieka. Podkreślając znaczenie treści o charakterze rozrywkowym Bundesverfassungsgericht zaakcentował, że stanowią one jeden z ważnych czynników przyciaggnięcia uwagi społecznej, w tym również na tematy, które znajdują się w zakresie zainteresowania publicznego. Dzięki nim jest przekazywana rzeczywistość, służą one do wywoływania tematów do dyskusji dotyczących stylu życia, wartości, wzorów zachowania, wypełniając w ten sposób ważną społecznie rolę.

Zgodnie $\mathrm{z}$ orzecznictwem Bundesverfassungsgericht ukazywanie sprzeczności między sposobem, w jaki osoby powszechnie znane kreują swój wizerunek publicznie a ich prywatnym życiem znajduje się w interesie publicznym. Uzasadnieniem tego poglądu jest trafna obserwacja, że osoby powszechnie znane stanowią wzorzec i model, pełnią funkcję autorytetu w demokratycznym społeczeństwie. Bundesgerichtshof w wyroku wydanym po orzeczeniu Europejskiego Trybunału Praw Człowieka z 24 VI 2004 r. uznał, że interesem informacyjnym społeczeństwa są objęte nie tylko przypadki ujawniania niezgodności między publicznie kreowanym wizerunkiem a prawdziwym sposobem życia, informowania o skandalach czy zachowaniach sprzecznych z moralnością lub prawem, ale również normalność życia codziennego osób powszechnie znanych, jeżeli okoliczności te służą budowaniu opinii publicznej na tematy objęte interesem społecznym ${ }^{18}$. Dodatkowo, zakres chronionych wolnością prasy artykułów prasowych obejmuje także treści o rozrywkowym charakterze odnoszące się do życia prywatnego i codziennego prominentów ${ }^{19}$. Bundesverfassungsgericht stoi na stanowisku, że budowanie opinii publicznej i dostarczanie rozrywki nie stanowią przeciwieństw, gdyż

18 Zob. seria wyroków Bundesgerichtshof, m.in. wyrok BGH z 6 III 2007 r., VI ZR 13/06 - Ernst August von Hannover, GRUR 2007, z. 6, s. 525; wyrok BGH z 6 III 2007 r., VI ZR 51/06 - Caroline von Hannover, GRUR 2007, z. 6, s. 528.

19 N. Klass, Anmerkung zu BVerfG, Beschluss vom 26 II 2008 - 1 BvR 1602/07, 1 BvR 1606/07, 1 BvR 1626/07, ZUM 2008, z. 5, s. 433. 
również poprzez materiały o charakterze rozrywkowym może odbywać się budowanie opinii w społeczeństwie.

Omówione stanowisko Bundesverfassungsgericht znajduje akceptację w doktrynie niemieckiej. Podkreśla się także, że ochrona wolności prasy nie jest uzależniona od rodzaju prasy. Nie należy więc dokonywać rozróżnienia według treści publikacji, dzieląc je na wnoszące wkład do ogólnej debaty politycznej albo zaspokajające interes rozrywkowy społeczeństwa, gdyż stałoby to w sprzeczności z zasadami wolnego demokratycznego społeczeństwa ${ }^{20}$. Treść publikacji prasowej jest jednak brana pod uwage przy ocenie istnienia naruszenia prawa do prywatności. Przedstawiciele piśmiennictwa podkreślają, że publikacje zdjęć i informacji z prywatnej sfery życia usprawiedliwia nie tylko polityczny interes społeczeństwa. Interes publiczny nie może być ograniczony wyłącznie do tematów publicznych, oficjalnych, powiązanych z działalnością państwa, ważnych dla budowania opinii publicznej ${ }^{21}$. Uznaje się, że prasa powinna samodzielnie, zgodnie z własnymi kryteriami publicystycznymi decydować, co uznaje za mieszczące się w interesie społecznym ${ }^{22}$. Codzienne życie gwiazd, użycie przedmiotów konsumpcyjnych, rozwój i styl życia są również zaliczane do uzasadnionej tematyki, którymi powinny zajmować się media. $\mathrm{Z}$ tego też względu interes publiczny powinien być rozumiany szeroko.

Szerokie rozumienie interesu publicznego w prawie niemieckim wynika wprost $\mathrm{z}$ wyodrębnianych $\mathrm{w}$ doktrynie i orzecznictwie funkcji prasy. Obok bowiem funkcji informacyjnej i kontrolnej na gruncie prawa niemieckiego jest wyraźnie zaznaczana i podkreślana funkcja rozrywkowa, jaką pełni prasa w społeczeństwie demokratycznym. Pogląd ten implikuje przyjęcie, że w interesie publicznym znajduje się informowanie o życiu prywatnym osób pełniących funkcje publiczne i osób powszechnie znanych - o sposobie spędzania wolnego czasu, życiu codziennym, stylu życia. Wydaje się, że tak szerokie ujęcie interesu publicznego jest nieuzasadnione i prowadzi do nadmiernej i nieproporcjonalnej ingerencji

20 M. Holoubek, ,, Caroline” und die Rechtsprechung des EGMR zu Art 10 EMRK, w: Caroline und die Folgen: Medienfreiheit am Wendepunkt?, Österreichische Juristenkommission, Wien 2005, s. 16.

21 K.-H. Lauder, Schutzpflicht gegenüber privaten Gefährdungen, w: Handbuch des Persönlichkeitsrecht, red. H.-P. Götting, Ch. Schertz, W. Seitz, München 2008, s. 185.

22 Ibidem, s. 181. 
w prawo do poszanowania życia prywatnego. Nie uwzględnia również woli jednostki pozostawania w spokoju. Należy zgodzić się z argumentami niemieckiej doktryny i orzecznictwa, że osoby tzw. życia publicznego wywierają olbrzymi wpływ na społeczeństwo, są uważane za autorytety i wzór do naśladowania. Jednakże nie usprawiedliwia to naruszania ich prywatności i autonomii informacyjnej przejawiającej się w możliwości podejmowania samodzielnej decyzji odnośnie udostępniania faktów ze sfery ich życia prywatnego, zwłaszcza w sytuacji, gdy osoby te nie prezentują publicznie określonego stanowiska, które wymagałoby weryfikacji.

W procesach o naruszenie dóbr osobistych przed sądami polskimi prasa - odwołując się do interesu społecznego istniejącego w informowaniu o zjawiskach społecznych - stara się usprawiedliwiać naruszenie prywatności osób powszechnie znanych. Przykładem przyjęcia takiej „linii obrony” przez prasę jest sprawa zakończona wyrokiem Sądu Apelacyjnego w Warszawie $\mathrm{z}$ dnia 17 grudnia $2008 \mathrm{roku}^{23} \mathrm{z}$ powództwa aktorki Joanny Brodzik. Przedmiotem procesu były publikacje, które ukazały się w dzienniku „Fakt - Gazeta Codzienna”. Tytuły publikacji brzmiały: Joanna Brodzik. Urode puszczasz z dymem, Nikotyna kradnie młodość, Joasiu, rzuć papierosy. Materiały prasowe zawierały m.in. zdjęcie aktorki palącej papierosa oraz przerobione zdjęcie Joanny Brodzik, na którym wygląd jednej połowy jej twarzy został poddany komputerowej obróbce poprzez naniesienie na twarz zmarszczek, bruzd i tzw. kurzych łapek. Zdjęcie stanowiło fragment artykułu zatytułowanego: Joasiu, czy tak chcesz wygladać? Publikowane materiały prasowe relacjonowały sposób spędzania wolnego czasu przez aktorkę, wizyty w salonie kosmetycznym, informowały, że aktorka pali papierosy. Artykuły opatrzone były serią zdjęć wykonanych z ukrycia przedstawiających aktorkę palącą papierosy czy wychodzącą z salonu kosmetycznego.

Broniąc się przed zarzutami naruszania prawa do prywatności Joanny Brodzik prasa starała się wykazać, że na swoich łamach dużo miejsca poświęca skutkom palenia tytoniu. Publikowane były bowiem wcześniej informacje, że członkowie sejmowej komisji zdrowia podczas przerw w obradach palą papierosy, że jeden z posłów rzucił palenie. Sąd Apelacyjny w Warszawie nie podzielił jednak linii obrony prezentowanej przez „Fakt”. Wskazał bowiem, że o ile „Fakt” zajmował się negatywnymi

23 Wyrok SA w Warszawie z 17 grudnia 2008 r., VI ACa 997/08, niepubl. 
skutkami palenia tytoniu, to nie przybrało to formy zorganizowanej kampanii antynikotynowej. Słabość do używek, korzystanie z usług salonu kosmetycznego i palenie tytoniu bezpośrednio po skorzystaniu z tych usług sądy obu instancji słusznie zaliczyły do sfery osobistej człowieka podlegającej ochronie. Sąd I instancji uznał za chybiony argument pozwanych odnośnie wykorzystania dóbr osobistych Joanny Brodzik w celu realizacji interesu publicznego mającego przejawiać się w kreowaniu mody na niepalenie i pokazywaniu negatywnych skutków palenia tytoniu. Opublikowane artykuły i zdjęcia w żaden bowiem sposób nie realizowały misji społecznej, a jedynie zaspokajały ciekawość czytelników co do prywatnej sfery życia osób powszechnie znanych. Prezentowanie zakwestionowanych materiałów prasowych nie stanowiło realizacji z góry założonego planu. Sąd uznał, że sposób działania prasy polegał na uzyskaniu zdjęć powódki w pierwszej kolejności, a następnie stworzeniu na ich podstawie tekstu dotyczącego następstw palenia, a nie odwrotnie. Tekst o szkodliwości palenia był więc jedynie pretekstem do publikacji sensacyjnych materiałów zdjęciowych dotyczących Joanny Brodzik.

Sąd Apelacyjny w Warszawie odniósł się również do powoływanego przez pozwanych argumentu dotyczącego konieczności weryfikacji postawy aktorki. W uzasadnieniu wyroku trafnie wskazano, że zamieszczenie zdjęć powódki palącej papierosy i informowanie czytelników o jej nałogu nie mogło służyć wykazaniu sprzeczności zachowania powódki z głoszoną przez nią postawą, bo aktorka nigdy nie zajmowała żadnej publicznie ogłaszanej postawy w istotnych kwestiach społecznych, a zwłaszcza w kwestii palenia papierosów czy mody na niepalenie.

W orzecznictwie został wyrażony pogląd, że powoływanie się przez prasę na konieczność weryfikacji postaw głoszonych przez osoby powszechnie znane $\mathrm{z}$ ich prawdziwym zachowaniem nie stanowi usprawiedliwienia dla naruszenia ich prywatności ${ }^{24}$. Istnieje wprawdzie społeczna potrzeba dokonywania takiej weryfikacji z uwagi na fakt, że m.in. aktorzy stają się obecnie idolami i wzorami do naśladowania oraz kształtują wzorce zachowań zwłaszcza wśród młodego pokolenia ${ }^{25}$. Jednakże weryfikacja jest dopuszczalna jedynie w przypadku spełnienia dwóch wa-

24 Wyrok Sądu Apelacyjnego w Warszawie z 25 I 2007 r., VI ACa 809/06, niepubl.

25 Wyrok Sądu Apelacyjnego w Warszawie z 25 I 2007 r., VI ACa 809/06, niepubl. 
runków: po pierwsze, informacje dotyczące zachowań danej osoby muszą być prawdziwe oraz po drugie, zachowania danej osoby muszą pozostawać $\mathrm{w}$ sprzeczności z publicznie głoszoną przez nią postawą ${ }^{26}$. Jeżeli warunki te nie są spełnione, wówczas artykuł prasowy nie służy ochronie interesu publicznego.

Odmiennie natomiast przedstawia się dopuszczalność weryfikacji głoszonych postaw z rzeczywistymi zachowaniami w odniesieniu do polityków. W orzecznictwie wskazuje się, że wizerunek i obraz polityka w oczach wyborców kształtowany jest nie tylko poprzez prezentowane przez niego racje merytoryczne i poglądy przedstawiane w wypowiedziach publicznych, ale również poprzez formę ich prezentowania oraz sposób zachowania się na forum niepublicznym. W ten sposób ujawnia się osobowość, charakter i kultura osobista polityka, które podlegają ocenie opinii społecznej ${ }^{27}$. Inną miarę, jeżeli chodzi o weryfikację głoszonych postaw, orzecznictwo stosuje w odniesieniu do osób, które swoją postawą, życiem czy działalnością prezentują określone wartości czy działają na rzecz dobra innych osób. W tym kontekście Sąd Najwyższy uznał za dopuszczalne informowanie o prywatnych zdarzeniach z życia przewodniczącego terenowego oddziału Komitetu Ochrony Praw Dziecka - o jego postępowaniu w życiu prywatnym, poglądach na temat wychowania dzieci, obowiązków rodzicielskich, wypełniania obowiązku alimentacyjnego ${ }^{28}$. Informacje te mają bowiem wpływ na społeczną ocenę tej osoby jako osoby uprawnionej i zobowiązanej do działań na rzecz dobra dzieci. Do grona osób, które swoją postawą prezentują określone wartości i w stosunku do których bardziej uzasadniona wydaje się weryfikacja postaw Sąd Apelacyjny w Warszawie w wyroku z 10 VI 2008 r. zaliczył m.in. księdza, lekarza, nauczyciela, sędziego i adwokata. W odniesieniu do tej kategorii osób ocenie społeczeństwa podlega nie tylko ich działalność publiczna, ale także zachowania w życiu prywatnym ${ }^{29}$.

Prasa wykorzystuje informacje z życia prywatnego osób powszechnie znanych pod pretekstem informowania czytelników o sprawach

26 Wyrok Sądu Apelacyjnego w Warszawie z 25 I 2007 r., VI ACa 809/06, niepubl.

Wyrok SN z 30 X 2003 r., IV CK 149/02, „LEX” nr 209289.

28 Wyrok SN z 11 V 2007 r., I CSK 47/07, „Rejent” 2007, nr 5, s. 173.

29 VI ACa 1648/07, Apel.-W-wa 2009, nr 1, poz. 9. Zob. również J. Sieńczyło-Chlabicz, Prawo do ochrony sfery życia prywatnego osób publicznych..., op. cit., s. 10 . 
- w jej przekonaniu - społecznie ważnych. Informując o miejscach, w których przebywają celebryci, komentując sposób wydawania pieniędzy, informując o pokusach nabywania rzeczy zbędnych, którym ulegają osoby znane, prasa twierdzi, że realizuje interes społeczny, pisząc o negatywnych zjawiskach społecznych, podczas gdy w rzeczywistości ujawnia jedynie szczegóły z życia prywatnego ${ }^{30}$.

W sprawie zakończonej wyrokiem Sądu Apelacyjnego w Warszawie z 15 września 2009 r. $^{31}$ prasa powoływała się na działanie w interesie społecznym dla uzasadnienia rozpowszechniania informacji, że powód - były prezenter telewizyjny Piotr Gembarowski - posługiwał się pseudonimem i zdjęciami innej osoby używając portalu randkowego w Internecie. Sądy obu instancji trafnie wskazały, że jeżeli prasa miała na celu zwrócenie uwagi na niepożądane zjawisko, że osoby, które korzystają z tzw. portali randkowych moga posługiwać się pseudonimami i nie swoimi wizerunkami, nie było konieczne odwoływanie się do konkretnej osoby powoda.

Wnioski płynące z orzecznictwa Sądu Najwyższego i sądów powszechnych oraz z poglądów przedstawicieli doktryny pozwalają na doprecyzowanie pojęcia interesu publicznego i określenie, kiedy dana publikacja służy realizacji tego interesu. Należy wskazać, że zgodnie z orzecznictwem Sądu Najwyższego interes publiczny aktualizuje się w sytuacji, gdy rozpowszechniana informacja dotyczy lub może dotyczyć bliżej nieoznaczonej grupy ludzi lub całego społeczeństwa i z punktu widzenia tych osób zasługuje na poparcie lub krytykę. Stanowisko takie zostało zaprezentowane w wyroku Sądu Najwyższego z 8 II 2008 r. ${ }^{32}$ Podkreślić należy, że już wcześniej w literaturze, w glosie do uchwały Sądu Najwyższego z 18 II 2005 r. ${ }^{33}$ P. Sobolewski trafnie definiował interes publiczny jako korzyść, wartość, którą społeczeństwo odnosi z publikacji prasowej. Glosator podkreślał, że interes jest urzeczywistniany poprzez rozpowszechnianie ważkich społecznie, prawdziwych i rzetelnych informacji ${ }^{34}$. Informacje nie mogą być rozpowszechniane w obronie partykularnych interesów, lecz w interesie ogółu lub części społeczeństwa.

30 Wyrok SA w Warszawie z 16 października 2009 r., VI ACa 317/09, niepubl.

31 Wyrok SA w Warszawie z 15 września 2009 r., VI ACa 120/09, niepubl.

32 I CSK 334/07, „LEX” nr 457843.

33 III CZP 53/04, „OSP” 2005, nr 9, poz. 110.

34 P. Sobolewski, Glosa do uchwaty SN z 18 II 2005 r., III CZP 53/04, „OSP” 2005, nr 12, poz. 144 . 
Wydaje się, że stanowisko to zasługuje na poparcie. Działanie w interesie publicznym powinno być realizowane w celu ochrony interesów zbiorowych. Nie jest to równoznaczne z interesem społeczeństwa jako całości. Interes publiczny aktualizuje się również w sytuacji działania na rzecz określonej grupy społecznej, np. mniejszości narodowych czy społeczności lokalnej. Należy jednocześnie podkreślić, że dla uznania, iż tematyka publikacji prasowej realizuje interes publiczny nie wystarczy zainteresowanie społeczeństwa określoną problematyką. Konieczne jest ponadto, aby problematyka ta była słuszna, uzasadniona i miała na celu realizację jakiegoś wyższego dobra, aniżeli zaspokajanie ciekawości społeczeństwa.

W oparciu o analizę orzecznictwa Sądu Najwyższego i sądów powszechnych możliwe jest wskazanie katalogów: pozytywnego i negatywnego publikowanych informacji, które służą - bądź nie - realizacji interesu publicznego. W interesie publicznym leżą między innymi informacje: służące realizacji zasadny jawności życia publicznego, dotyczące krytyki funkcjonowania organów państwowych, o charakterze społeczno-wychowawczym oraz mające na celu weryfikację głoszonych poglądów z zachowaniem osoby.

Natomiast do katalogu negatywnego zostały w orzecznictwie zaliczone następujące okoliczności, których publikacja nie stanowi działania $\mathrm{w}$ interesie publicznym:

1) publikowanie nieprawdziwych informacji dotyczących życia prywatnego;

2) ujawnianie danych personalnych i informacji z życia prywatnego w związku z informowaniem o wydarzeniach publicznych;

3) ujawnianie informacji o charakterze prywatnym $\mathrm{i}$ intymnym w celu zaspokojenia ciekawości społeczeństwa.

Ad 1) Występowanie interesu publicznego zależne jest od prawdziwości rozpowszechnianych informacji ${ }^{35}$. Wskazuje się, że nie jest usprawiedliwione powoływanie się na uzasadniony interes publiczny w sytuacji, gdy publikowane informacje nie są prawdziwe. Rozpowszechnianie niesprawdzonych i niezweryfikowanych informacji, jak również stawianie gołosłownych lub niedostatecznie sprawdzonych zarzutów nie leży

35 I CSK 334/07, „LEX” nr 457843. Zob. również wyrok SN z 19 IX 2002 r., II CKN 929/00, „LEX” nr 55568 oraz postanowienie SN z 22 VI 2004 r., V KK 70/04, „OSNKW" 2004, nr 9, poz. 86. Zob. również J. Sieńczyło-Chlabicz, Glosa do uchwaty SN z 18 II 2005 r., III CZP 53/04, „PiP” 2005, z. 7, s. 114-116. 
w społecznie uzasadnionym interesie ${ }^{36}$. W przypadku fałszywości informacji powoływanie się na działanie w obronie słusznego interesu prywatnego lub społecznego nie wyłącza bezprawności naruszenia ${ }^{37}$. Należy zgodzić się z poglądem P. Sobolewskiego, który zaznacza, że rozpowszechnianie fałszywych, nieprawdziwych informacji nigdy nie realizuje ważnego interesu publicznego. Autor uważa nawet, że rozpowszechnianie nieprawdy godzi $w$ ten interes ${ }^{38}$.

W związku z powyższym stanowiskiem należy stwierdzić, że interes publiczny jako przesłanka wyłączająca bezprawność aktualizuje się tylko w odniesieniu do informacji i zarzutów mających cechy prawdziwości. Podkreślenia wymaga, że w odniesieniu do dobra osobistego, jakim jest prawo do prywatności, bez znaczenia pozostaje okoliczność, czy informacja dotycząca prywatnej sfery życia jest prawdziwa czy nie. Istotne jest bowiem tylko to czy ingeruje ona $\mathrm{w}$ chroniony obszar prywatności ${ }^{39}$. Zagadnienie prawdziwości ma szczególne znaczenie w przypadku naruszenia czci i dobrego imienia jednostki. W odniesieniu do informacji z zakresu prywatnej sfery życia nieprawdziwość publikowanych informacji wpływa na stopień naruszenia prywatności i wysokość zasądzonego zadośćuczynienia, nie decyduje jednak o samym fakcie naruszenia.

Ad 2) W orzecznictwie sądowym wyraźnie zaznaczone jest rozróżnienie między informowaniem o zdarzeniach od informowania o osobach będących uczestnikami tych wydarzeń. Wskazuje się, że należy rozróżnić interes opinii publicznej w informowaniu o zdarzeniach od interesu opinii publicznej w ujawnianiu danych personalnych osób w nich uczestniczących ${ }^{40}$. W pierwszej z tych sytuacji opisywane w prasie zdarzenie stanowi egzemplifikację społecznie doniosłej problematyki, za której ujawnieniem przemawia legitymowany interes opinii publicznej. Natomiast

36 Wyrok SN z 17 X 2001 r., IV KKN 165/97, „OSNKW” 2002, nr 3-4, poz. 28. Zob. również J. Sieńczyło-Chlabicz, Dozwolona krytyka..., op. cit., s. 45.

37 Wyrok SA w Białymstoku z 25 I 2001 r., I ACa 4/01, „OSA” 2001, nr 9, poz. 51 .

38 P. Sobolewski, Glosa do uchwaty SN z 18 II 2005 r., III CZP 53/04, „OSP” 2005, nr 12, poz. 144; J. Sieńczyło-Chlabicz, Glosa do uchwaty SN z 18 II 2005 r., III CZP 53/04, „PiP” 2005, z. 7, s. 114-115; J. Sieńczyło-Chlabicz, Glosa do wyroku SN z 7 XI 2002 r., II CKN 1293/00, „PiP” 2004, z. 4, s. 119-120.

39 Zob. wyrok SA w Białymstoku z 25 I 2001 r., I ACa 4/01, „OSA” 2001, nr 9, poz. 51 .

40 Wyrok SA w Krakowie z 5 XII 2001 r., I ACa 986/01, „TPP” 2002, nr 3, s. 143. 
uzasadniony interes w ujawnianiu danych osobowych identyfikujących osoby uczestniczące występuje jedynie w sytuacji, gdy identyfikacja wyraża określoną wartość informacyjną dla opinii publicznej, a więc gdy opisywane zdarzenie jest istotne z punktu widzenia pełnionej przez tę osobę roli społecznej ${ }^{41}$. W przeciwnym wypadku za nieuzasadnione należy uznać ujawnianie danych personalnych umożliwiających identyfikację osoby.

Sąd Najwyższy stwierdził, że powoływanie się na prawo do przedstawiania i krytyki zjawisk nie usprawiedliwia naruszenia sfery życia prywatnego osoby. Takie stanowisko zostało wyrażone w wyroku z 6 XII 1990 r. $^{42} \mathrm{~W}$ przedmiotowej sprawie ujawnione informacje dotyczyły procesu rozwodowego powódki i jej męża, przyczyn rozkładu ich pożycia małżeńskiego, w tym m.in. toczącej się przeciwko mężowi powódki sprawy karnej za znęcanie i zapadłego w tym postępowaniu wyroku skazującego. Pozwani - twórcy audycji pt. Osąźmy sami w swojej obronie przytaczali argument, że celem ich działań było zwrócenie uwagi na niesłuszne skazanie męża powódki. Należy podzielić stanowisko A. Szpunara, który komentując stanowisko Sądu Najwyższego podkreślił, że telewizja nie powinna przejmować na siebie funkcji wymiaru sprawiedliwości ${ }^{43}$. Wyemitowana audycja nie stanowiła bowiem właściwego środka obrony społecznie uzasadnionego interesu, ponieważ roztrząsanie szczegółów życia prywatnego powódki nie było usprawiedliwione, co więcej, tematyka ta nie znajdowała się w obszarze społecznego zainteresowania ${ }^{44}$. Sąd Najwyższy trafnie zauważył, że wybór tematu przez dziennikarzy nie zawsze odpowiada rzeczywistemu społecznemu zainteresowaniu informacją, zaś $\mathrm{w}$ tej sprawie brak było sygnałów o istnieniu zapotrzebowania na poruszaną problematykę $e^{45}$. J Serda $\mathrm{w}$ glosie aprobującej do omawianego wyroku rozważał również, czy w audycji nie można by dopatrzyć się uzasadnionego interesu społecznego z uwagi na ujawnianie powszechnej praktyki składania przez żony doniesień do organów ścigania o przestępstwa znęcania, aby polepszyć swoją sytuację

41 Wyrok SA w Krakowie z 5 XII 2001 r., I ACa 986/01, „TPP” 2002, nr 3, s. 143.

42 I CR 575/90, „OSP” 1992, nr 10, poz. 214.

43 A. Szpunar, Glosa do wyroku SN z 6 XII 1990 r., I CR 575/90, „Przegląd Sądowy" 1992, nr 1, s. 91.

44 Ibidem, s. 93.

45 Wyrok SN z 6 XII 1990 r., I CR 575/90, „OSP” 1992, nr 10, poz. 214. 
w procesie rozwodowym. Autor uznał jednak, że wątpliwe jest, aby ta argumentacja uzasadniała interes społeczny w nadaniu audycji ${ }^{46}$.

Wydaje się, że stanowisko to jest trafne. Informowanie o określonym problemie czy anomaliach życia społecznego, a nawet tendencjach i trendach, może leżeć w uzasadnionym interesie publicznym. Natomiast ujawnianie danych personalnych osób, których dotyczy tematyka artykułu czy programu telewizyjnego może stanowić nieuzasadnioną - z perspektywy celu publikacji w postaci ukazania określonego problemu społecznego - ingerencję w ich prawo do prywatności.

Ad 3) Sąd Najwyższy wielokrotnie wyrażał stanowisko, że powołanie się na ważny interes publiczny nie wyłącza bezprawności działania prasy w sytuacji, gdy materiał prasowy dotyczy wyłącznie spraw prywatnych, takich jak losy małżeństwa, stan majątkowy, wiek, zawód, data ślubu i plany życiowe, wyjazd męża w celach zarobkowych do Turcji i jego tragiczna śmierć, zakończona podziałem majątku wspólnego i działem spadku między żoną a teściami ${ }^{47}$. Istotne jest, że tak szczegółowe i dokładne przytoczenie faktów i zdarzeń z prywatnej sfery życia - nawet bez podania nazwisk - pozwala na identyfikację osób będących bohaterami reportażu. Stanowi więc bezprawną ingerencję w ich dobra osobiste.

Zgodnie z poglądem Sądu Najwyższego nieuzasadnione jest publikowanie informacji ujawniających przeszłość kobiety, która przed zawarciem małżeństwa była prostytutką ${ }^{48}$. Przy ocenie bezprawności naruszenia dóbr osobistych Sąd Najwyższy zwrócił uwagę na fakt, że zamierzeniem dziennikarza nie było zajęcie się prostytucją jako profesją społecznie naganna, a artykuł nie zawierał jakichkolwiek walorów społeczno-wychowawczych $^{49}$. W ten sposób Sąd Najwyższy dał wyraz stanowisku, iż w niniejszej sprawie publikacja danych ze sfery życia intymnego nie służyła obronie społecznie uzasadnionego interesu, gdyż nie zajmowała się problemem w ogóle, lecz ujawniała jedynie fakty intymne z życia kobiety. Trafnie ocenia tę sytuację A. Kopff wskazując, iż działanie $\mathrm{w}$ interesie społecznym poprzez zwalczanie niepożądanego zjawiska społecznego nie usprawiedliwia działań dziennikarza, ponieważ nie wy-

46 J. Serda, Glosa do wyroku SN z 6 XII 1990 r., I CR 575/90, „OSP” 1992, nr 10, poz. 214.

47 I CR 400/83, „OSNC” 1984, nr 11, poz. 195.

48 Wyrok SN z 11 III 1986 r., I CR 4/86, „OSP” 1987, nr 4, poz. 86.

49 Wyrok SN z 11 III 1986 r., I CR 4/86, „OSP” 1987, nr 4, poz. 86. 
maga szczególnej „ilustracji” w postaci ujawnienia faktów wchodzących w skład sfery życia intymnego ${ }^{50}$. Już wcześniej Sąd Najwyższy w wyroku z 13 VI 1980 r. uznał, że cel artykułu, którym było rozpowszechnienie informacji, że powód zatrudniał w swoim zakładzie niepełnoletnie dziewczynki, nie uzasadniał publikowania informacji należących do prywatnej sfery jego życia. Społeczny interes w publikacji artykułu nie usprawiedliwiał więc relacjonowania faktów z życia osobistego. Artykuł osiagnnąłby swój cel niezależnie od ilustrowania go wiadomościami prywatnymi $^{51}$.

Na podkreślenie zasługuje pogląd Sądu Najwyższego, że realizacja celu polegającego na zaspokojeniu ciekawości dotyczącej tzw. osób publicznych nie uchyla bezprawności naruszenia dóbr osobistych. Wzgląd na fakt, że sprawa bulwersuje znaczną część opinii publicznej nie stanowi właściwego środka do ochrony uzasadnionego interesu społecznego czy prywatnego ${ }^{52}$. Godne przywołania jest stanowisko R. Stefanickiego, który stwierdził, że pogoń za sensacją i troska o przyciągnięcie czytelnika zbyt często przeważają nad rzetelnym dziennikarstwem. Cele te nie stanowią uzasadnionego interesu, z uwagi na który może być wyłączona bezprawność wkroczenia w cudzą prywatność. Wolność prasy wymaga, aby uwzględniać interes dziennikarza w przekazywaniu informacji w sprawach publicznie ważnych. Do spraw takich należą m.in. nurtujące społeczeństwo i budzące usprawiedliwione zainteresowanie opinii publicznej zagadnienia dotyczące nadużycia władzy w celach prywatnych ${ }^{53}$.

Reasumując należy wskazać, że nawet pobieżna analiza treści tytułów prasowych występujących na polskim rynku dowodzi, że tabloidyzacja prasy jest zjawiskiem nagminnym. Dziennikarze, starając się pozyskać jak największe grono odbiorców, dążą do przedstawienia przekazywanych informacji w sposób jak najbardziej przystępny, atrakcyjny i lekki. Efekt ten uzyskiwany jest poprzez zastosowanie techniki infotainment

50 A. Kopff, Glosa do wyroku SN z 11 III 1986 r., I CR 4/86, „OSP” 1987, nr 4, poz. 86.

51 IV CR 182/80, „OSNC” 1981, nr 2-3, poz. 30; Z. Bidziński, J. Serda, Cywilnoprawna ochrona dóbr osobistych w praktyce sqdowej, w: Dobra osobiste i ich ochrona w polskim prawie cywilnym. Zagadnienia wybrane, red. J. St. Piątowski, Wrocław-Warszawa-Kraków-Gdańsk-Lódź 1986, s. 72.

52 II CKN 559/99, „OSP” 2002, nr 12, poz. 161.

53 R. Stefanicki, Glosa do wyroku SN z 11 X 2001 r., II CKN 559/99, „OSP” 2002, nr 12, poz. 161 . 
i prezentowanie treści informacyjnych w formie rozrywkowej. W tym celu prasa stara się dokonać personalizacji przekazywanych treści, ukazując przykłady z życia osób powszechnie znanych, które są bardziej atrakcyjne dla odbiorców.

Stanowisko sądów niemieckich, zgodnie z którym również normalność życia codziennego osób powszechnie znanych, czyli de facto prywatność, służą budowaniu opinii publicznej na tematy objęte interesem społecznym, wydaje się być niebezpieczne. Akceptuje ono bowiem występującą $\mathrm{w}$ mediach praktykę przekazywania informacji za pomocą infotainment, która skutkuje naruszeniem prywatności. Zaakcentować należy, że niemal każde zagadnienie można przedstawić posiłkując się przykładami z życia prywatnego osób powszechnie znanych. W konsekwencji prowadzi to do ujawniania faktów ze sfery prywatności celebrytów pod pretekstem relacjonowania o sprawach społecznie ważnych.

$\mathrm{Na}$ aprobatę zasługuje natomiast stanowisko polskiego Sądu Najwyższego i sądów powszechnych, zgodnie z którym publikowanie nieprawdziwych informacji dotyczących życia prywatnego, ujawnianie danych personalnych i informacji z życia prywatnego w związku z informowaniem o wydarzeniach publicznych czy ujawnianie informacji o charakterze prywatnym i intymnym w celu zaspokojenia ciekawości społeczeństwa, nie stanowi działania $\mathrm{w}$ interesie publicznym. Tym samym nie wyłącza bezprawności naruszenia dóbr osobistych osób, o których relacjonuje prasa.

Należy zgodzić się, że funkcja rozrywkowa stanowi ważne zadanie, które powinna realizować prasa. Jednakże w porównaniu z funkcją informacyjną i kontrolną, realizowaniem prawa obywateli do ich rzetelnego informowania, jawności życia publicznego oraz kontroli i krytyki społecznej, funkcja rozrywkowa ma zdecydowanie mniejsze znaczenie. Dlatego też - w konfrontacji z wartością, jaką stanowi konstytucyjnie chronione prawo do prywatności - musi ustapić.

\section{Infotainment and the protection of the privacy of commonly known individuals}

\section{Summary}

This paper focuses on the personalization of information, in particular as regards commonly known individuals and the issue of privacy infringement. It should be indicated that tabloids and infotainment are characterized by mixing entertainment 
with news, paying more attention to people than to issues, and transforming social and human tragedies so they become a topic of public discussion for the purpose of providing entertainment. Information is now conveyed by means of human stories, concrete examples taken from the world of well-known people. This leads to the privacy of this category of people being infringed. 